University of Nebraska - Lincoln

DigitalCommons@University of Nebraska - Lincoln

\title{
Drought Effects On Water Quality In The South Platte River Basin, Colorado
}

Lori A. Sprague

U.S. Geological Survey, sprague@usgs.gov

Follow this and additional works at: https://digitalcommons.unl.edu/usgsstaffpub

Sprague, Lori A., "Drought Effects On Water Quality In The South Platte River Basin, Colorado" (2005). USGS Staff -- Published Research. 611.

https://digitalcommons.unl.edu/usgsstaffpub/611

This Article is brought to you for free and open access by the US Geological Survey at DigitalCommons@University of Nebraska - Lincoln. It has been accepted for inclusion in USGS Staff -- Published Research by an authorized administrator of DigitalCommons@University of Nebraska - Lincoln. 


\title{
DROUGHT EFFECTS ON WATER QUALITY IN THE SOUTH PLATTE RIVER BASIN, COLORADO ${ }^{1}$
}

\author{
Lori A. Sprague ${ }^{2}$
}

\begin{abstract}
Twenty-three stream sites representing a range of forested, agricultural, and urban land uses were sampled in the South Platte River Basin of Colorado from July through September 2002 to characterize water quality during drought conditions. With a few exceptions, dissolved ammonia, Kjeldahl nitrogen, total phosphorus, and dissolved orthophosphate concentrations were similar to seasonal historical levels in all land use areas during the drought. At some agricultural sites, decreased dilution of irrigation return flow may have contributed to higher concentrations of some nutrient species, increased primary productivity, and higher dissolved oxygen concentrations. At some urban sites, decreased dilution of base flow and wastewater treatment plant effluent may have contributed to higher dissolved nitrite-plus-nitrate concentrations, increased primary productivity, and higher dissolved oxygen concentrations. Total pesticide concentrations in urban and agricultural areas were not consistently higher or lower during the drought. At most forested sites, decreased dilution of ground water-derived calcium bicarbonate type base flow likely led to elevated $\mathrm{pH}$ and specific-conductance values. Water temperatures at many of the forested sites also were higher, contributing to lower dissolved oxygen concentrations during the drought.

(KEY TERMS: drought; water quality; agricultural hydrology; urban water management; nonpoint source pollution; wastewater.)
\end{abstract}

Sprague, Lori A., 2005. Drought Effects on Water Quality in the South Platte River Basin, Colorado. Journal of the American Water Resources Association (JAWRA) 41(1):11-24.

\section{INTRODUCTION}

Although much attention is focused on the physical availability of water supplies during a drought, the potentially deleterious effects of drought conditions on water quality also are a concern. Decreased streamflows could lead to decreased dilution of chemical constituents entering the stream through surface runoff, point source discharges, or ground water. In addition, smaller volumes of water in a stream could lead to higher instream water temperatures. The combination of higher water temperatures and increased nutrient concentrations also could lead to increased primary productivity, which in turn could lead to increased dissolved oxygen and $\mathrm{pH}$ levels during the day and decreased dissolved oxygen and $\mathrm{pH}$ levels at night.

Little direct evidence is available on the effects of drought because few monitoring studies have been conducted during moderate or severe droughts. Increased specific conductance has been observed as a result of decreased stream dilution capacity and increased influence of base flow during droughts (Caruso, 2002; Schindler, 1997). In contrast, decreased specific conductance has been observed in forested watersheds due to uptake of higher conductance subsurface flow by vegetation (Kobayashi et $a l ., 1990)$. In some studies of basins dominated by agricultural nonpoint sources, nitrogen and phosphorus concentrations were found to decrease during drought conditions. During the drought in 1998 and 1999 on the South Island of New Zealand, total phosphorus and total nitrogen concentrations were lower due to a lack of storm runoff and increased primary production (Caruso, 2002). Similarly, during low flows in the Gulf Coastal Plain of southwestern Georgia in the United States, dissolved ammonia and soluble reactive phosphorus decreased during low flows because the hydraulic connection between the floodplains and the streams was broken and because of retention of these constituents along subsurface flow paths (Golladay and Battle, 2002). In another study

\footnotetext{
1Paper No. 03184 of the Journal of the American Water Resources Association (JAWRA) (Copyright (C) 2005). Discussions are open until August 1, 2005.

2Hydrologist, U.S. Geological Survey, Denver Federal Center, P.O. Box 25046, MS 415, Lakewood, Colorado 80225 (E-Mail:lsprague@usgs. gov).
} 
encompassing urban as well as agricultural areas, some nutrient species were found to decrease, while others increased. During the drought in 1976 and 1977 in the Sangamon River Basin of Illinois, average concentrations of nitrite-plus-nitrate decreased at all stream sites as a result of reduced agricultural runoff, while ammonia concentrations increased in response to reduced dilution of wastewater effluent at some sites (Muchmore and Dziegielewski, 1983).

During 2002, drought conditions occurred throughout Colorado, including the South Platte River Basin. The South Platte River originates in the Rocky Mountains of central Colorado at the Continental Divide and flows about 725 kilometers northeast across the Great Plains to its confluence with the North Platte River at North Platte, Nebraska (Figure 1). As of 2004, more than 2.8 million people were living in the Front Range urban corridor along the base of the Rocky Mountains in the South Platte River Basin; the population increased by about 670,000 people between 1990 and 2000 (U.S. Census Bureau, 2000). On the plains downstream from the Denver metropolitan area, population densities are small, and the land is used primarily for agriculture and livestock production. The South Platte River is one of the most regulated rivers in the United States (Dennehy et al., 1995). Much of the water in the river comes from snowmelt runoff from the Rocky Mountains during spring and early summer; interbasin transfers of water from the Colorado, Arkansas, and North Platte River Basins bring additional water into the basin. Water is moved and stored by means of a complex network of ditches and reservoirs throughout the basin for irrigation, municipal water supply, and power generation (Dennehy et al., 1995). During low flow periods in the late summer, fall, and winter, urban runoff, wastewater treatment plant discharge, and irrigation return flow can contribute substantially to flow in the river.

Drought conditions previously have occurred in the South Platte River Basin, including major droughts during the 13th and 16th Centuries and moderate droughts in the 1930s and 1950s (Woodhouse et al., 2002); however, during the summer of 2002 there was an unprecedented combination of low streamflow and urban and agricultural development. Snowpack levels in the Upper South Platte and Upper Colorado River Basins - two major sources of water in the South

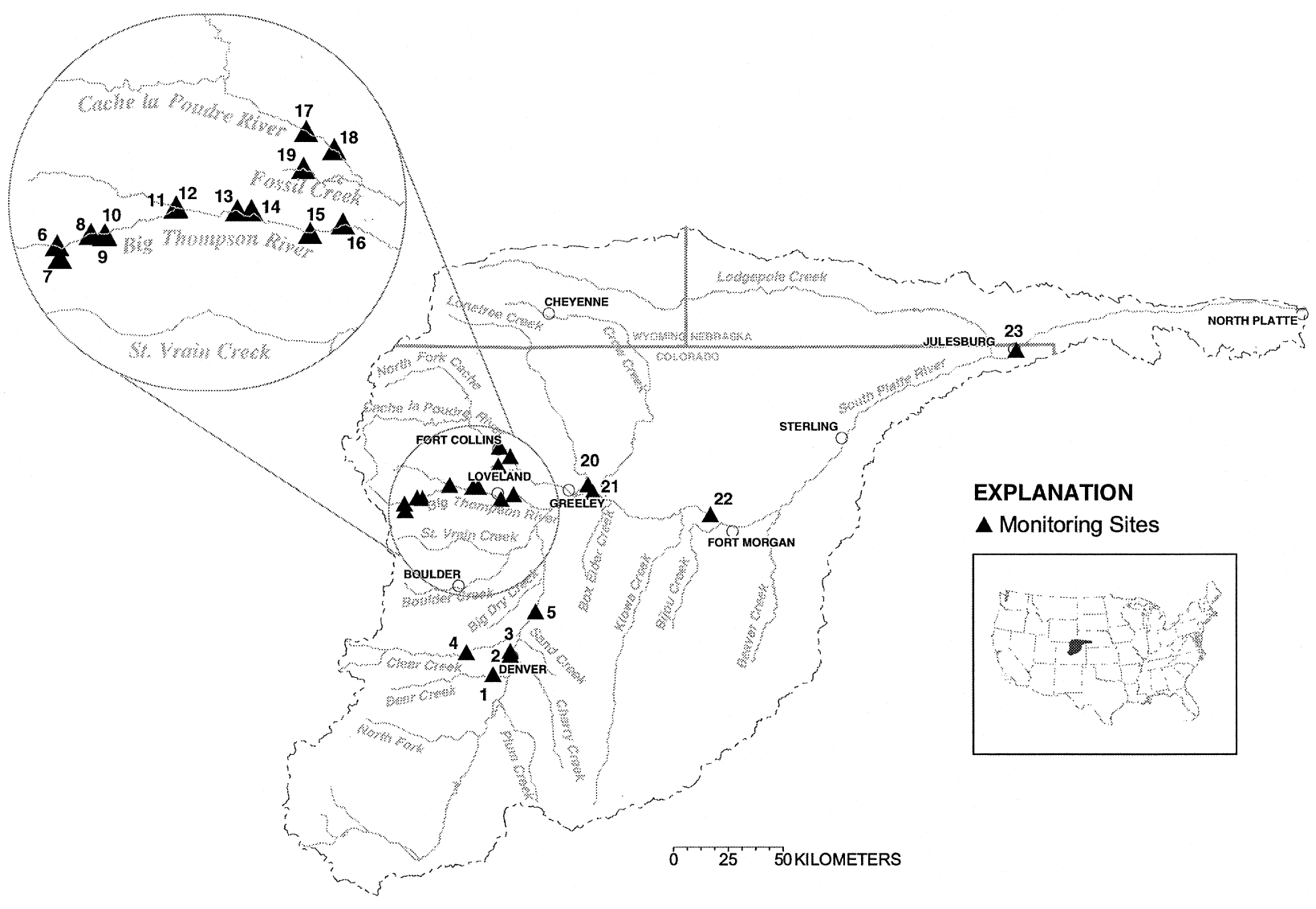

Figure 1. Map Showing the Location of Monitoring Sites in the South Platte River Basin. 
Platte River Basin - were at 32 and 36 percent, respectively, of their long term averages in 2002 at the time of their typical peaks in early to mid-April (Denver Water, 2004). Statewide precipitation levels in Colorado during the period from July 2001 through June 2002 were at the lowest level of any single year since 1895 (NOAA, 2002). Values of the local Palmer Drought Index - an index of the scope, severity, and frequency of prolonged periods of abnormally dry or wet weather - ranged from -3.37 to -7.27 throughout the South Platte River Basin during the summer of 2002 , indicating severe to extreme drought conditions (Colorado State University, 2004). The U.S. Geological Survey (USGS) completed a synoptic monitoring study in the basin from July through September 2002; the primary objective of the study was to characterize water quality conditions during the drought.

\section{SITE SELECTION AND SAMPLING}

The USGS, in cooperation with numerous federal, state, and local agencies, operates an ongoing network of about 25 water quality sampling sites on rivers and streams throughout the South Platte River Basin. Historical data from many of these sites span multiple years and, therefore, a wide range of climatic and streamflow conditions. To take advantage of ongoing monitoring activities and historical data, the selection of sites for the synoptic network primarily focused on existing or former sites in the basin. However, monitoring at existing or former sites had been initiated on a variety of dates to meet a variety of information needs, and thus the sites did not provide representative coverage of land uses within basin. Additional new sampling sites were added to the drought synoptic network to expand the spatial coverage of monitoring across the basin, but limited funding did not allow for the addition of enough sites to obtain evenly distributed coverage of all land uses. In the end, the 23 stream sites ultimately selected for the synoptic network (Figure 1 and Table 1) included sites in forested, agricultural, and urban land uses, but most sites were in forested areas.

All sites were sampled for a consistent set of core water quality constituents - $\mathrm{pH}$, dissolved oxygen, specific conductance, dissolved nitrite, dissolved nitrite-plus-nitrate, dissolved ammonia, Kjeldahl nitrogen (dissolved or total), total phosphorus, and dissolved orthophosphate - to facilitate comparison of results across sites. Select agricultural and urban sites also were sampled for 48 common pesticides. All samples were collected by USGS personnel using standardized depth integrating and width integrating techniques (USGS, 2004). Measurements were obtained in the field for water temperature, $\mathrm{pH}$, dissolved oxygen, and specific conductance; and samples were processed and preserved onsite using standard methods described in USGS (2004). Nutrient and pesticide samples were analyzed at the USGS National Water Quality Laboratory in Denver, Colorado, by using methods described in Fishman (1993) and Zaugg et al. (1995).

Samples were collected from July through September 2002, after the traditional snowmelt runoff period. During 2002, however, there was minimal snowmelt runoff in the basin; as a result, stream discharges were at extremely low levels during the study period. Heavy localized thunderstorms did occur periodically, however, causing brief peaks in discharge during the study period. To ensure that the synoptic samples did not contain substantial storm runoff, real-time discharge data transmitted via satellite were closely monitored for each site to determine when streamflows had returned to near prestorm levels. If there was no gage at a site, discharge at nearby gages was monitored; if there were no nearby gages, local weather patterns in the drainage area were tracked to determine the potential for elevated discharge at a site.

\section{DATA ANALYSIS}

Drought related changes in water quality were examined in three ways. First, the drought data from July through September 2002 were compared to historical data from January 1980 through September 2001, where available, on a site-by-site basis. Only historical data from July through September (hereinafter referred to as "seasonal historical" data) were included. Because only one or two drought samples were collected at each site, there were not enough data for a statistical comparison of the drought and seasonal historical samples. Instead, the drought data were compared to the 5th and 95th percentiles of the seasonal historical data to distinguish low or high values during the drought from typical diurnal and annual variability at an individual site. The 5 th and 95th percentiles were used to provide more conservative criteria for determining low or high values during the drought than the 10th and 90th percentiles or the 25 th and 75 th percentiles would, because many parameters have large diurnal fluctuations (e.g., due to light availability) or annual fluctuations (e.g., due to interbasin water transfers) that potentially could confound the identification of drought related changes. It is still possible that some normal diurnal maximum or minimum values for individual parameters would be incorrectly deemed "drought-related" 
TABLE 1. Summary of Sites and Constituents Sampled During the Drought Synoptic Study.

\begin{tabular}{|c|c|c|c|c|c|c|c|c|c|}
\hline \multirow{3}{*}{$\begin{array}{l}\text { Site } \\
\text { Number } \\
(\text { from } \\
\text { Figure 1) }\end{array}$} & \multirow{3}{*}{$\begin{array}{c}\text { U.S. Geological } \\
\text { Survey Station } \\
\text { ID }\end{array}$} & \multirow[b]{3}{*}{$\begin{array}{l}\text { U.S. Geological Survey } \\
\text { Station Name }\end{array}$} & \multirow{3}{*}{$\begin{array}{l}\text { Predominant } \\
\text { Upstream } \\
\text { Land Use }\end{array}$} & \multicolumn{6}{|c|}{ Constituent Group } \\
\hline & & & & \multicolumn{2}{|c|}{$\begin{array}{c}\text { Field } \\
\text { Parameters } \\
\end{array}$} & \multicolumn{2}{|c|}{ Nutrients } & \multicolumn{2}{|c|}{ Pesticides } \\
\hline & & & & \#D & $\begin{array}{l}\text { Period of } \\
\text { Record }\end{array}$ & \#D & $\begin{array}{l}\text { Period of } \\
\text { Record }\end{array}$ & \#D & $\begin{array}{l}\text { Period of } \\
\text { Record }\end{array}$ \\
\hline 1 & 393948105053501 & $\begin{array}{l}\text { Bear Creek Below Estes } \\
\text { Road at Lakewood, } \\
\text { Colorado }\end{array}$ & Urban & 2 & - & 2 & - & 0 & - \\
\hline 2 & 06713500 & $\begin{array}{l}\text { Cherry Creek at Denver, } \\
\text { Colorado }\end{array}$ & Urban & 2 & $\begin{array}{l}(1980-2002)^{a, b} \\
1993-1995 \\
(2001-2002)^{c, d}\end{array}$ & 2 & $\begin{array}{l}1993-1995 \\
2001-2002\end{array}$ & 2 & $\begin{array}{l}1993-1994 \\
2001-2002\end{array}$ \\
\hline 3 & 06714000 & $\begin{array}{l}\text { South Platte River at } \\
\text { Denver, Colorado }\end{array}$ & Urban & 2 & $\begin{array}{l}1982-1984 \\
1993-2001\end{array}$ & 2 & $\begin{array}{l}(1980-1984)^{c} \\
1993-2001\end{array}$ & 2 & $\begin{array}{l}1993-1994 \\
1997-2001\end{array}$ \\
\hline 4 & 06719505 & $\begin{array}{l}\text { Clear Creek at Golden, } \\
\text { Colorado }\end{array}$ & Forest & 2 & $\begin{array}{l}(1981-1984, \\
1985-1988, \\
1996-2002)^{\mathrm{a}, \mathrm{b}} \\
1993-1995\end{array}$ & 2 & $\begin{array}{l}1981-1984 \\
1993-1995\end{array}$ & 0 & - \\
\hline 5 & 06720500 & $\begin{array}{l}\text { South Platte River at } \\
\text { Henderson, Colorado }\end{array}$ & Urban & 2 & $\begin{array}{l}(19890-1984)^{b} \\
1988-2001\end{array}$ & 2 & $1988-2002$ & 2 & 1994,2001 \\
\hline 6 & 402114105350101 & $\begin{array}{l}\text { Big Thompson Below } \\
\text { Moraine Park Near } \\
\text { Estes Park, Colorado }\end{array}$ & Forest & 2 & $\begin{array}{l}1995-1998 \\
2001-2002\end{array}$ & 2 & $\begin{array}{l}1995-1998 \\
2001-2001\end{array}$ & 2 & 2001-2002 \\
\hline 7 & 09013000 & $\begin{array}{l}\text { Alva B. Adams Tunnel at } \\
\text { East Portal Near Estes } \\
\text { Park, Colorado }\end{array}$ & Forest & 2 & $1980-2001$ & 2 & $1980-2001$ & 0 & - \\
\hline 8 & 06733000 & $\begin{array}{l}\text { Big Thompson River at } \\
\text { Estes Park, Colorado }\end{array}$ & Forest & 2 & $\begin{array}{l}(1981-1983)^{b} \\
2000-2002\end{array}$ & 2 & $2000-2002$ & 0 & - \\
\hline 9 & 06734900 & $\begin{array}{l}\text { Olympus Tunnel at Lake } \\
\text { Estes, Colorado }\end{array}$ & Forest & 2 & 1980-2002 & 2 & $198-2002$ & 0 & - \\
\hline 10 & 06735500 & $\begin{array}{l}\text { Big Thompson River Near } \\
\text { Estes Park, Colorado }\end{array}$ & Forest & 2 & $\begin{array}{l}(1980-1983)^{b} \\
2000-2002\end{array}$ & 2 & $2000-2002$ & 0 & - \\
\hline 11 & 402554105202100 & $\begin{array}{l}\text { Big Thompson River Above } \\
\text { North Fork Big Thompson } \\
\text { River at Drake, Colorado }\end{array}$ & Forest & 2 & 2000-2002 & 2 & $2000-2002$ & 0 & - \\
\hline 12 & 06736000 & $\begin{array}{l}\text { North Fork Big Thompson } \\
\text { River at Drake, Colorado }\end{array}$ & Forest & 2 & 2000-2002 & 2 & $2000-2002$ & 0 & - \\
\hline 13 & 402533105124300 & $\begin{array}{l}\text { Big Thompson River Below } \\
\text { Sulzer Gulch Near Loveland, } \\
\text { Colorado }\end{array}$ & Forest & 2 & 2000-2002 & 2 & 2000-2002 & 0 & - \\
\hline 14 & 402535105105700 & $\begin{array}{l}\text { Buckhorn Creek at County } \\
\text { Road 24, Near Loveland, } \\
\text { Colorado }\end{array}$ & Forest & 1 & - & 1 & - & 0 & - \\
\hline 15 & 06741510 & $\begin{array}{l}\text { Big Thompson River at } \\
\text { Loveland, Colorado }\end{array}$ & Forest & 2 & 1980-2002 & 2 & $1980-2002$ & 0 & - \\
\hline 16 & 06741530 & $\begin{array}{l}\text { Big Thompson River at } \\
\text { Interstate } 25 \text { Near } \\
\text { Loveland, Colorado }\end{array}$ & Forest & 2 & $\begin{array}{l}1987-1992 \\
2001-2002\end{array}$ & 2 & $\begin{array}{l}1987-1992 \\
2001-2002\end{array}$ & 2 & - \\
\hline 17 & 06752260 & $\begin{array}{l}\text { Cache La Poudre River at } \\
\text { Fort Collins, Colorado }\end{array}$ & Forest & 2 & 1980-2002 & 2 & $1980-2002$ & 0 & - \\
\hline
\end{tabular}


TABLE 1. Summary of Sites and Constituents Sampled During the Drought Synoptic Study (cont'd.).

\begin{tabular}{|c|c|c|c|c|c|c|c|c|c|}
\hline \multirow{3}{*}{$\begin{array}{l}\text { Site } \\
\text { Number } \\
\text { (from } \\
\text { Figure 1) }\end{array}$} & \multirow{3}{*}{$\begin{array}{c}\text { U.S. Geological } \\
\text { Survey Station } \\
\text { ID }\end{array}$} & \multirow[b]{3}{*}{$\begin{array}{l}\text { U.S. Geological Survey } \\
\text { Station Name }\end{array}$} & \multirow{3}{*}{$\begin{array}{l}\text { Predominant } \\
\text { Upstream } \\
\text { Land Use }\end{array}$} & \multicolumn{6}{|c|}{ Constituent Group } \\
\hline & & & & \multicolumn{2}{|c|}{$\begin{array}{c}\text { Field } \\
\text { Parameters }\end{array}$} & \multicolumn{2}{|c|}{ Nutrients } & \multicolumn{2}{|c|}{ Pesticides } \\
\hline & & & & \#D & $\begin{array}{l}\text { Period of } \\
\text { Record }\end{array}$ & \#D & $\begin{array}{l}\text { Period of } \\
\text { Record }\end{array}$ & \#D & $\begin{array}{l}\text { Period of } \\
\text { Record }\end{array}$ \\
\hline 18 & 06752280 & $\begin{array}{l}\text { Cache La Poudre River } \\
\text { Above Boxelder Creek } \\
\text { Near Timnath, Colorado }\end{array}$ & Forest & 2 & $1980-2002$ & 2 & $1980-2002$ & 2 & 2001 \\
\hline 19 & 403048105042701 & $\begin{array}{l}\text { Fossil Creek at College } \\
\text { Avenue at Fort Collins, } \\
\text { Colorado }\end{array}$ & Agriculture & 2 & - & 2 & - & 2 & - \\
\hline 20 & 06753990 & $\begin{array}{l}\text { Lonetree Creek Near } \\
\text { Greeley, Colorado }\end{array}$ & Agriculture & 1 & $\begin{array}{l}1993-1995 \\
2001-2002\end{array}$ & 1 & $\begin{array}{l}1993-1995 \\
2001-2002\end{array}$ & 1 & $\begin{array}{l}1993-1994 \\
2001-2002\end{array}$ \\
\hline 21 & 06754000 & $\begin{array}{l}\text { South Platte River Near } \\
\text { Kersey, Colorado }\end{array}$ & Agriculture & 2 & $\begin{array}{l}1980 \\
(1981-1982)^{b} \\
1993-2002\end{array}$ & 2 & $\begin{array}{l}1980,1991 \\
1993-2002\end{array}$ & 2 & $\begin{array}{l}1994 \\
1997-2002\end{array}$ \\
\hline 22 & 06758500 & $\begin{array}{l}\text { South Platte River Near } \\
\text { Weldona, Colorado }\end{array}$ & Agriculture & 2 & $1980-2002$ & 2 & $1980-2002$ & 0 & 1994 \\
\hline 23 & 06764000 & $\begin{array}{l}\text { South Platte River at } \\
\text { Julesburg, Colorado }\end{array}$ & Agriculture & 1 & $\begin{array}{l}1980-1995 \\
2001\end{array}$ & 1 & 1980-1995 & 0 & 1994,2001 \\
\hline
\end{tabular}

aSpecific conductance.

bWater temperature.

$\mathrm{c}_{\mathrm{pH}}$.

dDissolved oxygen.

eTotal Kjeldahl nitrogen.

- , no data collected.

\#D, number of drought synoptic samples collected.

through this analysis, so multiple lines of evidence (e.g., nutrients, dissolved oxygen, and $\mathrm{pH}$ ) were used for interpretation whenever possible. Hereinafter, "elevated" drought values are those above the 95th percentile of the seasonal historical data, and "depressed" drought values are those below the 5th percentile of the seasonal historical data. For example, at Site 2, the 95th percentile of the seasonal historical dissolved oxygen data was 9.6 milligrams per liter; the concentration during one of the drought samples was 10.4 milligrams per liter, an "elevated" drought value. Describing general water quality conditions at these sites was not an objective of the study; thus, percentiles are used here instead of raw data to focus on the drought response at each site and to decrease the overall volume of information presented.

Second, the sites were grouped by predominant land use to look at general patterns of drought response at all sites within a single land use and to compare the patterns of drought response among different land uses. Drought response was measured by using the percentile rank of the drought samples when grouped with the seasonal historical samples at a given site. Because the data were not always normally distributed, a two-sided Kruskal-Wallis rank sum test using S-Plus was performed to compare percentile ranks among different land uses (Insightful Corp., 2000). Land use percentages were determined by combining the 1990 National Land Cover Dataset (Vogelmann et al., 2001) with basin boundaries delineated from the National Elevation Dataset (USGS, 1999). The criteria for classifying the predominant land use at each site is described in Table 2; the results are listed in Table 1 . The lower percentage criterion for Urban classification than for Agricultural classification resulted from spatial patterns associated with the two land uses in the South Platte River Basin - urban areas normally are concentrated near a monitoring site and thus may have a greater effect on water quality at lower percentages, while agricultural areas generally are more dispersed in the upstream drainage area. This assumption may be an oversimplification for some sites; therefore, results of the land use analyses should be interpreted more conservatively than results from the single-site analyses.

Third, the number of synoptic samples with concentrations outside Colorado State water quality standards during the drought was compared to the number of seasonal historical samples with 
TABLE 2. Criteria for Land Use Classification of Sites.

\begin{tabular}{cl}
\hline Site Classification & Criteria \\
\hline Urban & Urban Land Use $>4$ Percent and Agricultural Land Use $<15$ Percent* \\
Agricultural & Urban Land Use $<4$ Percent and Agricultural Land Use $>15$ Percent* \\
Forested & Urban Land Use $<4$ Percent and Agricultural Land Use $<15$ Percent \\
\hline
\end{tabular}

*When both urban land use $>4$ percent and agricultural land use $>15$ percent, the land use with the greatest percentage was chosen to classify the site; $>$, greater than. $<$, less than.

concentrations outside the standards. The State of Colorado categorizes all stream segments using four categories of classified uses - aquatic life, water supply, recreation, and agriculture (Colorado Department of Public Health and Environment, 2002). Water quality standards are set for each stream segment to protect its designated use(s); data from each study site were compared to the standards set for the designated use(s) in that stream segment. Because the number of drought samples differed substantially from the number of seasonal historical samples, the standard exceedance frequencies are presented as percentages.

\section{RESULTS AND DISCUSSION}

Stream gages were in operation at 10 of the 23 sites during the study period, and exceedance percentages for streamflow were calculated for those sites that had at least six years of data (Table 3 ). Flow duration analysis indicated that at 7 of the 10 sites, median daily discharge during the study period was equaled or exceeded more than 95 percent of the time historically July through September at that site.
At Site 2, discharge during the study period was regulated in part by a reservoir approximately 18 kilometers upstream; releases from the reservoir kept streamflow levels closer to the historical average than at most other sites. Similarly, discharge at Site 5 was moderated in part by regular releases from Denver's largest wastewater treatment plant approximately 14 kilometers upstream, and discharge at Site 23 was regulated by the minimum flow delivery requirements between Colorado and Nebraska dictated by the South Platte River Compact (Colorado General Assembly, 1923).

Although the median daily discharge during the study period was not exceptionally low at these three sites, in several instances the instantaneous discharge at the time of the synoptic water quality sampling was below the 5th percentile of the instantaneous discharge at the time of all historical water quality samples (Table 4). In these instances, the synoptic sampling occurred during the lowest flow conditions of the study period. The opposite was true at other sites such as Site 18 - while median daily discharge during the study period was exceptionally low, instantaneous discharge at the time of the synoptic sampling was not always exceptionally low relative to

TABLE 3. Flow Statistics for Sites with Operating Stream Gages in 2002 and With at Least Six Years of Additional Operation.

\begin{tabular}{|c|c|c|c|c|}
\hline Site Number & Period of Record & $\begin{array}{c}\text { Median } Q_{D} \\
\text { (in cubic meters } \\
\text { per second) }\end{array}$ & $\begin{array}{c}\text { Percent of Time } Q_{D} \\
\text { Equaled or } \\
\text { Exceeded by } Q_{\mathbf{H}}\end{array}$ & $\begin{array}{c}\text { Number of Days } \\
\mathbf{Q}_{D} \text { Less Than the } \\
\text { 5th Percentile of } \mathbf{Q}_{\mathbf{H}}\end{array}$ \\
\hline 2 & 1942 to 2001 & 0.28 & 64 & 0 \\
\hline 3 & 1895 to 2001 & 1.8 & 95 & 53 \\
\hline 4 & 1975 to 2001 & 1.6 & 99 & 90 \\
\hline 5 & 1926 to 2001 & 4.7 & 79 & 2 \\
\hline 6 & 1995 to 2001 & 0.54 & 95 & 89 \\
\hline 18 & 1980 to 2001 & 0.050 & 99 & 70 \\
\hline 20 & 1993 to 2001 & 0.00085 & 99 & 90 \\
\hline 21 & 1901 to 2001 & 2.4 & 96 & 57 \\
\hline 22 & 1953 to 2001 & 2.5 & 99 & 66 \\
\hline 23 & 1902 to 2001 & 0.54 & 87 & 2 \\
\hline
\end{tabular}

$\mathrm{Q}_{\mathrm{D}}$, daily mean discharge from July through September 2002.

$\mathrm{Q}_{\mathrm{H}}$, daily mean discharge from July through September over the period of record. 
TABLE 4. Summary of the Number of Elevated or Depressed Values in the Drought Data Relative to the Seasonal Historical Data.

\begin{tabular}{|c|c|c|c|c|c|c|c|c|c|c|c|}
\hline $\begin{array}{l}\text { Site } \\
\text { No. }\end{array}$ & $\begin{array}{c}\text { Instan- } \\
\text { taneous } \\
\text { Discharge }\end{array}$ & $\begin{array}{c}\text { Water } \\
\text { Temperature }\end{array}$ & $\mathbf{p H}$ & $\begin{array}{c}\text { Dissolved } \\
\text { Oxygen }\end{array}$ & $\begin{array}{c}\text { Specific } \\
\text { Conductance }\end{array}$ & $\begin{array}{l}\text { Dissolved } \\
\text { Ammonia }\end{array}$ & $\begin{array}{c}\text { Dissolved } \\
\text { Nitrite- } \\
\text { Plus- } \\
\text { Nitrate }\end{array}$ & $\begin{array}{l}\text { Dissolved } \\
\text { Nitrite }\end{array}$ & $\begin{array}{l}\text { Kjeldahl } \\
\text { Nitrogen }\end{array}$ & $\begin{array}{c}\text { Total } \\
\text { Phos- } \\
\text { phorus }\end{array}$ & $\begin{array}{c}\text { Dissolved } \\
\text { Ortho- } \\
\text { phosphate }\end{array}$ \\
\hline 1 & - & - & - & - & - & - & - & - & - & - & - \\
\hline 2 & 2 & 1 & 0 & 1 & 0 & 1 & 1 & 0 & $\mathbf{1}^{\mathrm{b}}$ & 0 & 0 \\
\hline 3 & 1 & 0 & 0 & 2 & 0 & 0 & 2 & 0 & $1^{\mathrm{a}}$ & 0 & 1 \\
\hline 4 & 2 & 0 & 0 & 0 & 2 & 0 & 0 & 2 & $2^{\mathrm{a}}$ & 0 & 0 \\
\hline 5 & 1 & 0 & 1 & 0 & 1 & 0 & 0 & 1 & $1^{\mathrm{a}}$ & 0 & 0 \\
\hline 6 & 1 & 1 & 1 & 0 & 0 & 0 & 1 & 0 & $1^{\mathrm{a}}$ & 0 & 2 \\
\hline 7 & 0 & 1 & 1 & 0 & 1 & 0 & 0 & - & $0^{b}$ & 0 & 0 \\
\hline 8 & 1 & 0 & 0 & 1 & 1 & 0 & 0 & - & $0^{b}$ & 0 & 0 \\
\hline 9 & 0 & 1 & 1 & 0 & 1 & 0 & 1 & - & $0^{\mathrm{b}}$ & 0 & 0 \\
\hline 10 & 1 & 1 & 1 & 1 & 1 & 0 & 0 & - & $1^{b}$ & 1 & 0 \\
\hline 11 & 1 & 1 & 1 & 1 & 1 & 1 & 1 & - & $1^{b}$ & 1 & 1 \\
\hline 12 & 1 & 1 & 0 & 1 & 0 & 0 & 0 & - & $1^{b}$ & 0 & 0 \\
\hline 13 & 1 & 1 & 1 & 1 & 1 & 0 & 1 & - & $0^{\mathrm{b}}$ & 1 & 1 \\
\hline 14 & - & - & - & - & - & - & - & - & - & - & - \\
\hline 15 & 0 & 0 & 0 & 1 & 0 & 1 & 0 & - & $0^{\mathrm{b}}$ & 0 & 2 \\
\hline 16 & 1 & 0 & 0 & 0 & 1 & 0 & 1 & - & $1^{b}$ & 0 & 0 \\
\hline 17 & 0 & 0 & 0 & 1 & 0 & 0 & 1 & 1 & - & - & 0 \\
\hline 18 & 0 & 0 & 0 & 0 & 0 & 0 & 0 & 1 & - & - & 0 \\
\hline 19 & - & - & - & - & - & - & - & - & - & - & - \\
\hline 20 & 1 & 0 & 0 & 1 & 0 & 1 & 0 & 0 & $0^{\mathrm{b}}$ & 1 & 0 \\
\hline 21 & 2 & 0 & 0 & 1 & 0 & 1 & 1 & 2 & $1^{b}$ & 0 & 1 \\
\hline 22 & 1 & 0 & 0 & 0 & 0 & 0 & 0 & 1 & $0^{b}$ & 1 & 1 \\
\hline 23 & 0 & 0 & 0 & 0 & 0 & 0 & 1 & 0 & $0^{b}$ & 0 & 0 \\
\hline
\end{tabular}

aDissolved Kjeldahl nitrogen.

bTotal Kjeldahl nitrogen.

Notes: Values in regular font represent "elevated" drought samples (above the 95th percentile of the seasonal historical data); values in bold represent "depressed" drought samples (below the 5th percentile of the seasonal historical data); values in italics represent one "elevated' drought sample and one "depressed" drought sample. --, no seasonal historical data.

the historical water quality samples. It is possible that small amounts of storm water runoff, irrigation return flow, or reservoir releases were contributing to the flow in these streams at the time of sampling.

\section{SITE-BY-SITE ANALYSIS}

Dissolved oxygen concentrations observed at four sites were elevated (above the 95th percentile of the seasonal historical data). At three of these sites Cherry Creek (Site 2) and South Platte River at Denver and near Kersey (Sites 3 and 21) - elevated concentrations of dissolved oxygen were accompanied by elevated concentrations of some nutrient species, which indicates increased primary productivity during the drought conditions. Values of $\mathrm{pH}$ at these sites neither contradicted nor directly supported this conclusion. Although $\mathrm{pH}$ values were not above the 95 th percentile of the seasonal historical data, they were still higher than many of the historical samples. At one other site - Lonetree Creek (Site 20) - elevated dissolved oxygen concentrations were accompanied by depressed (below the 5th percentile of the seasonal historical data) concentrations of some nutrient species. The depressed nutrient concentrations may be due to a high turnover rate; low nutrient concentrations in some very productive systems can result from high turnover related to high remineralization and uptake rates (Dodds et al., 2000). In addition, the amount of water reaching this site from upstream sources and nearby ground water discharge was decreasing dramatically at the time of sample collection, as evidenced by the fact that the site went completely dry approximately three weeks after the sample was collected. Nutrient inputs, therefore, likely also were decreasing at the time of sample collection.

Depressed dissolved oxygen concentrations were observed at eight sites. At five of the sites on the Big 
Thompson River - Sites 8, 10, 11, 12, and 13 - dissolved oxygen saturation was near 100 percent, which indicates minimal biological activity (Wetzel, 1983). Instead, it appears that the depressed dissolved oxygen concentrations largely were attributable to decreased solubility of oxygen at the warmer water temperatures observed at the sites. Although water temperatures were not above the 95 th percentile at Site 8 , they were still high compared to many of the seasonal historical samples. Depressed dissolved oxygen concentrations at two other sites - Big Thompson River at Loveland (Site 15) and Cache la Poudre River at Fort Collins (Site 17) - were accompanied by depressed concentrations of some nutrient species. The depressed dissolved oxygen concentrations observed in these morning samples in part may have been due to overnight respiration (Wetzel, 1983). Overnight respiration also may have contributed to the depressed dissolved oxygen concentrations at another site - Cherry Creek (Site 2) - where, in contrast, the depressed morning dissolved oxygen concentration was accompanied by elevated dissolved nitrite-plus-nitrate concentrations. The source of the elevated dissolved nitrite-plus-nitrate concentrations is unknown.

Elevated $\mathrm{pH}$ values were observed at six sites. At four of these sites on the Big Thompson River - Sites $6,10,11$, and 13 - elevated $\mathrm{pH}$ values were accompanied by elevated concentrations of nutrients, although not always the most biologically available forms of nitrogen or phosphorus. As previously discussed, at Sites 10, 11, and 13, little indication of biological activity was observed, suggesting that there was another cause of elevated $\mathrm{pH}$ values. Ground water discharging at these three sites flows through Paleozoic sedimentary rocks that include limestone and sandstone (Tweto, 1979); decreased instream dilution of the calcium bicarbonate type ground water during lower flows may have led to the observed elevated $\mathrm{pH}$ values. At the fourth site - Site 6 - ground water flows through Precambrian-age igneous and metamorphic rocks before discharging at the site; these rocks are less readily weathered and are not as likely to contribute to elevated $\mathrm{pH}$ values. Dissolved oxygen saturation levels at this site were 124 and 108 percent, and dissolved nitrite-plus-nitrate concentrations were elevated, which indicates that at this site, primary productivity likely was causing the elevated $\mathrm{pH}$ values. At two other sites - Alva B. Adams Tunnel at East Portal near Estes Park (Site 7) and Olympus Tunnel at Lake Estes (Site 9) - elevated $\mathrm{pH}$ values were not accompanied by elevated nutrient concentrations. It should be noted that water at the downstream end of these tunnels likely has spent insufficient time in contact with streambed substrate to have achieved equilibrium for constituents affected by biological processes; as a result, conclusions about the effects of production or respiration are difficult to make. However, it is possible that these elevated $\mathrm{pH}$ values may be due in part to decreased dilution of calcium bicarbonate-type ground water in the streams and reservoirs from which the tunnels originate.

Depressed $\mathrm{pH}$ values were observed at one site South Platte River at Henderson (Site 5) - where water in large part was comprised of wastewater treatment plant discharge. This sample was taken in the early afternoon when primary productivity would be expected to be high and, therefore, $\mathrm{pH}$ also would be expected to be high. The cause of the depressed $\mathrm{pH}$ value at this site is unknown.

Elevated specific conductance was observed at eight sites. Elevated $\mathrm{pH}$ also was observed at five of the eight sites: Alva B. Adams Tunnel (Site 7), Olympus Tunnel (Site 9), Big Thompson River near Estes Park (Site 10), Big Thompson River above North Fork of the Big Thompson River at Drake (Site 11), and Big Thompson River below Sulzer Gulch near Loveland (Site 13). As with $\mathrm{pH}$, the elevated specific conductance at these sites likely was due to decreased dilution of calcium bicarbonate type ground water. At two sites - Big Thompson River at Estes Park (Site 8) and Clear Creek (Site 4) - the elevated specific conductance was not accompanied by elevated $\mathrm{pH}$ values. Both of these sites are located near roads and small urban areas. At Site 4, both synoptic samples were collected within several days after localized storm events, although discharge at the time of sampling had returned to near prestorm levels. It is possible that runoff from these two storms entered the stream when streamflows were at very low levels relative to historical conditions, and the decreased dilution potential led to the elevated specific conductance values. Continuous discharge data for the study period are not available for Site 8, but it is possible that the same phenomenon occurred there as well. It also is possible that decreased dilution of calcium bicarbonate type ground water contributed to the elevated specific-conductance values at this site, although $\mathrm{pH}$ values were not correspondingly elevated. At the South Platte River at Henderson (Site 5), decreased dilution of wastewater effluent likely was the cause of the observed elevated specific conductance value. Elevated nitrite and Kjeldahl nitrogen observed at this site also indicate that decreased dilution of effluent was a factor. Examples of the response of specific conductance to changing streamflow conditions at three sites - Clear Creek at Golden (Site 4), a forested site affected by ground water inflow; South Platte River at Henderson (Site 5), an urban site affected by wastewater effluent; and South Platte River at Weldona (Site 22), an agricultural site affected by irrigation return flow - illustrate that in each land use, a decrease in 
dilution associated with decreased streamflow can lead to higher specific conductance values (Figure 2).

Depressed specific conductance was observed at one site - Big Thompson River at Interstate 25 near Loveland (Site 16). At the time of sample collection, instantaneous discharge at this site was 0.85 cubic meters per second, which, at the 40th percentile of the seasonal historical discharge, was not particularly low. The low specific conductance value may have resulted from the release of more dilute water from upstream reservoirs for irrigation downstream from the site. Continuous discharge data for the study period are not available for this site, so it is not possible to confirm this.

\section{LAND USE ANALYSIS}

Although the study was not designed expressly to address differences in land use, several patterns emerge when drought data, expressed as percentile ranks of seasonal historical data, are grouped by land use (Figure 3). At the agricultural sites, decreased instream dilution of irrigation return flow likely led to the generally higher specific conductance and dissolved nitrite-plus-nitrate concentrations in the drought samples relative to the seasonal historical samples. Increased primary productivity at the agricultural sites may have contributed to generally higher dissolved oxygen concentrations observed during the drought. At the forested sites, decreased instream dilution of the calcium bicarbonate type ground water during lower flows may have led to the observed elevated $\mathrm{pH}$ and specific conductance values in the drought samples. Additionally, warmer water temperatures likely contributed to lower dissolved oxygen concentrations at these sites during the drought. At the urban sites, decreased instream dilution of base flow and point source discharges likely led to the generally higher specific conductance and dissolved nitrite-plus-nitrate concentrations in the drought samples. As a byproduct of the higher dissolved nitrite-plus-nitrate concentrations, increased primary productivity likely led to the higher dissolved oxygen concentrations observed during the drought.

There were significant differences in the drought response of water temperature, dissolved oxygen concentrations, and dissolved nitrite-plus-nitrate concentrations among the three land use areas (Figure 3) due to differences in nutrient sources, stream size, and water management. At urban and agricultural sites, fertilizer application and point source discharges likely contributed to increased nitrite-plusnitrate concentrations and therefore increased primary productivity and increased dissolved oxygen

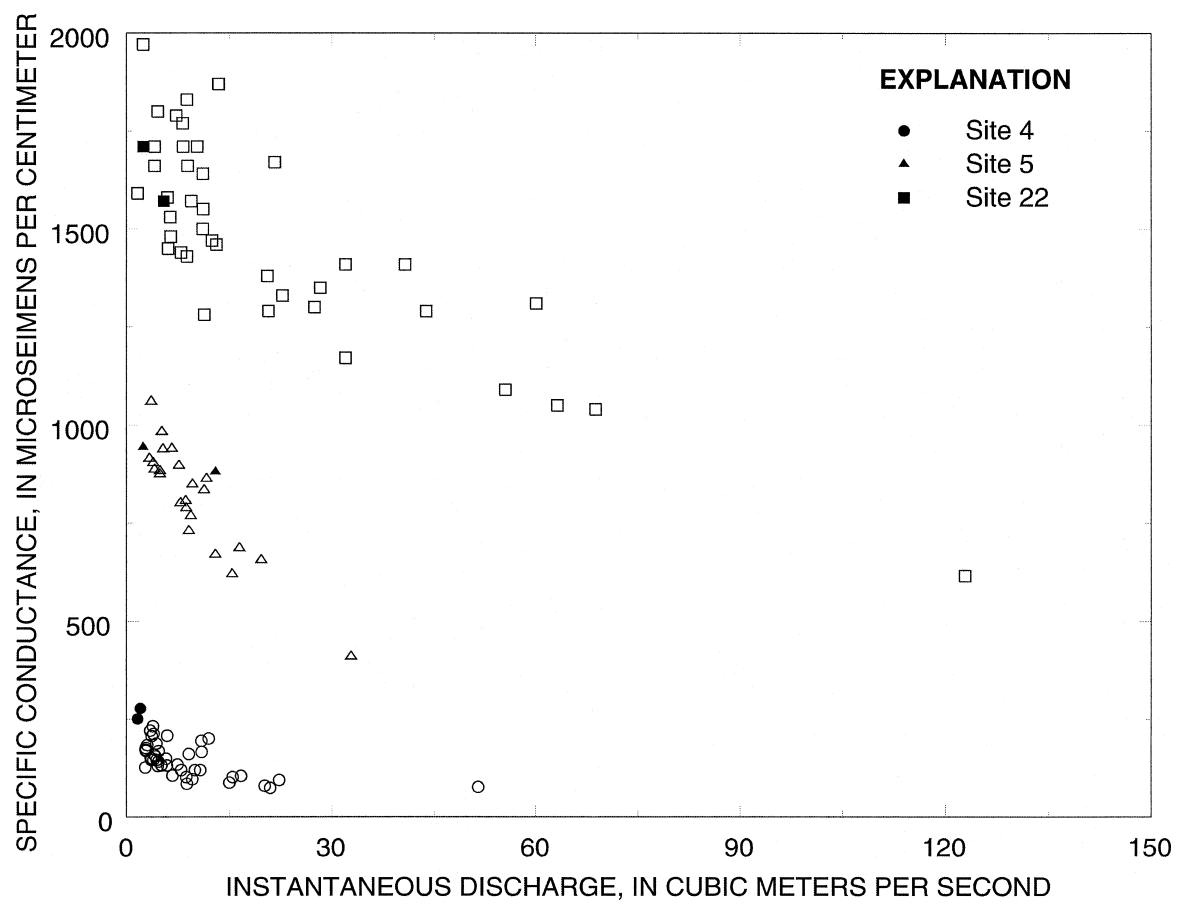

Figure 2. Scatter Plot Showing the Relation Between Instantaneous Discharge and Specific Conductance for a Forested Site (Site 4), an Urban Site (Site 5), and an Agricultural Site (Site 22). Seasonal historical samples are shown with open symbols and drought samples are shown with closed symbols. 

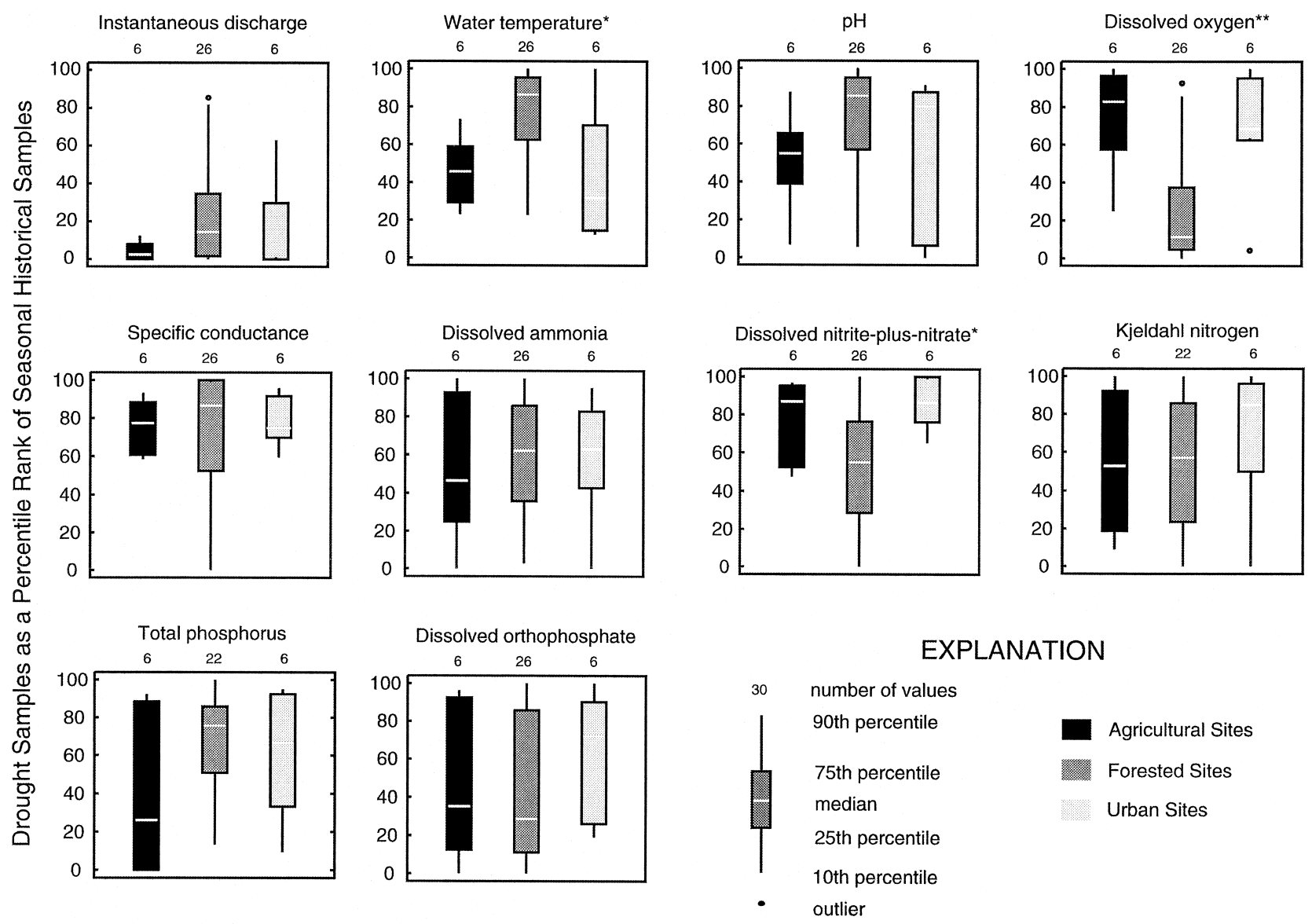

*Significantly different at $\alpha=0.05$ ${ }^{* *}$ Significantly different at $\alpha=0.01$

Figure 3. Boxplots Showing the Drought Samples as Percentile Ranks of the Seasonal Historical Samples for Field Parameters and Nutrients, by Land Use Category.

concentrations that were not observed throughout the forested areas. There was little evidence of increased primary productivity at the forested sites, primarily because there were few sources of nitrogen and phosphorus upstream. Instead, the behavior of dissolved oxygen at the forested sites largely was dependent on water temperature - higher water temperatures decreased oxygen solubility. The increased water temperatures at the forested sites during the drought were not observed in other parts of the basin, which may be due to more efficient heating of the smaller streams in the headwater forested areas and the addition of cooler water from reservoirs, point sources, or ground water to the streams in some localized urban and agricultural areas.

Concentrations of several constituents were not markedly higher or lower during the drought in any land use area (Figure 3). With a few exceptions, dissolved ammonia, Kjeldahl nitrogen, total phosphorus, and dissolved orthophosphate were near seasonal historical levels. This may have resulted from a balance between reduced storm runoff and reduced instream dilution, particularly for total phosphorus and Kjeldahl nitrogen, which are typically transported in the particulate phase in storm runoff. The lack of consistently increased dissolved orthophosphate and ammonia concentrations at sites influenced by wastewater treatment plant effluent in urban areas is somewhat surprising because of the potential for decreased dilution of effluent at low flows during the drought.

Pesticide samples were collected at nine sites during the synoptic; four of those sites only had one seasonal historical sample and were not included in further analysis here. At the remaining five sites, not enough seasonal historical data were collected to produce meaningful percentiles. Instead, the drought data were compared directly to the seasonal historical data (Figure 4). All four of the agricultural and urban sites sampled contained more than one pesticide, both historically and during the drought. No pesticides were detected at the forested site in any of the samples. Historically, a larger number of pesticides were 


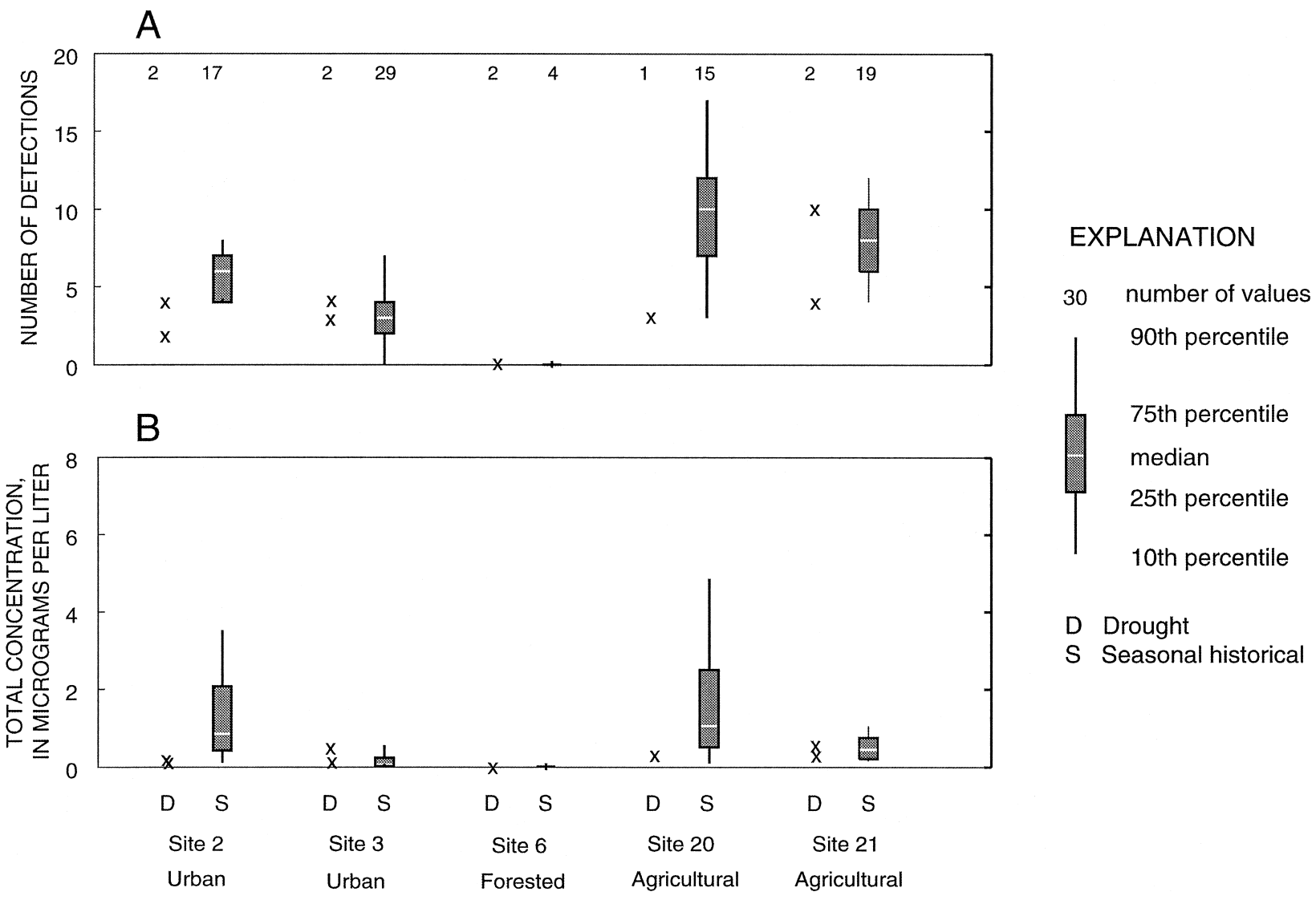

Figure 4. Boxplots Showing (A) the Total Number of Pesticides Detected and (B) the Total Pesticide Concentration, by Site.

detected in agricultural areas than in urban areas. During the drought, however, the number of detections was comparable between the two land use areas.

At two sites - South Platte River at Denver (Site 3) and South Platte River near Kersey (Site 21) - the number of detections and the total concentrations (the sum of concentrations of all pesticides detected in a sample) were higher than the seasonal historical median for one of the two drought samples. At two other sites - Cherry Creek (Site 2) and Lonetree Creek (Site 20) - the number of detections and the total concentrations were less than the seasonal historical median. It is difficult to separate the effects of the drought from changes in the timing, amount, and type of pesticides applied; pesticide use data are not available for urban areas and have not yet been fully compiled for agricultural areas, and it is possible that reductions in cultivated acreage may have occurred as a consequence of drought conditions.

\section{WATER-QUALITY STANDARDS EVALUATION}

Although the small number of samples collected during the drought synoptic limited the degree to which stream impairment could be assessed, some individual concentrations outside Colorado State water quality standards were observed. Values of $\mathrm{pH}$ above the standard were observed in one of two drought samples at three sites - Alva B. Adams Tunnel (Site 7), Olympus Tunnel (Site 9), and Big Thompson River near Estes Park (Site 10) (Table 5). In comparison, very few $\mathrm{pH}$ values outside the standard had been observed in the seasonal historical data at these sites, indicating that drought conditions were contributing to elevated $\mathrm{pH}$ values in these areas. Similarly, the percentage of concentrations above the dissolved nitrite standard at one site - South Platte River at Henderson (Site 5) - was higher in the drought samples than in the seasonal historical samples. This site was affected by wastewater effluent, which may have composed a relatively larger part of the total streamflow during the drought, leading to the higher percentage of concentrations above the standard. No exceedances of the Colorado dissolved 
TABLE 5. Summary of the Percentage of Nutrient and Field Parameters Outside Colorado State Water Quality Standards in the Drought Data Compared to the Seasonal Historical Data (drought/seasonal historical). ${ }^{a}$

\begin{tabular}{|c|c|c|c|c|c|}
\hline $\begin{array}{c}\text { Site } \\
\text { Number }\end{array}$ & $\mathbf{p H}$ & $\begin{array}{c}\text { Dissolved } \\
\text { Oxygen }\end{array}$ & $\begin{array}{c}\text { Dissolved } \\
\text { Ammonia } \\
\text { (acute) }\end{array}$ & $\begin{array}{c}\text { Dissolved } \\
\text { Nitrate }^{b}\end{array}$ & $\begin{array}{l}\text { Dissolved } \\
\text { Nitrite }\end{array}$ \\
\hline 1 & $0 /-$ & $0 /-$ & $0 /-$ & $0 /-$ & $0 /-$ \\
\hline 2 & $0 / 0$ & $0 / 0$ & $0 / 0$ & $0 / 0$ & $0 / 0$ \\
\hline 3 & $0 / 0$ & $0 / 0$ & $0 / 0$ & $0 / 0$ & $0 / 4$ \\
\hline 4 & $0 / 0$ & $0 / 0$ & $0 / 0$ & $0 / 0$ & $0 / 0$ \\
\hline 5 & $0 / 0$ & $0 / 0$ & $0 / 0$ & $0 / 0$ & $50 / 5$ \\
\hline 6 & $0 / 0$ & $0 / 0$ & $0 / 0$ & $0 / 0$ & $0 / 0$ \\
\hline 7 & $50 / 4$ & $0 / 4$ & $0 / 0$ & $-/ 0$ & $-/ 0$ \\
\hline 8 & $0 / 0$ & $0 / 0$ & $0 / 0$ & $-1-$ & $-1-$ \\
\hline 9 & $50 / 2$ & $0 / 0$ & $0 / 0$ & $-/ 0$ & $-/ 0$ \\
\hline 10 & $50 / 0$ & $0 / 0$ & $0 / 0$ & $-1-$ & $-1-$ \\
\hline 11 & $0 / 0$ & $0 / 0$ & $0 / 0$ & $-1-$ & $-1-$ \\
\hline 12 & $0 / 0$ & $0 / 0$ & $0 / 0$ & $-1-$ & $-1-$ \\
\hline 13 & $0 / 0$ & $0 / 0$ & $0 / 0$ & $-1-$ & $-1-$ \\
\hline 14 & $0 /-$ & $0 /-$ & $0 /-$ & $0 /-$ & $0 /-$ \\
\hline 15 & $0 / 0$ & $0 / 0$ & $0 / 0$ & $-/ 0$ & $-/ 0$ \\
\hline 16 & $0 / 0$ & $0 / 0$ & $0 / 0$ & $-/ 0$ & $-/ 0$ \\
\hline 17 & $0 / 0$ & $0 / 0$ & $0 / 0$ & $0 / 0$ & $0 / 0$ \\
\hline 18 & $0 / 1$ & $0 / 0$ & $0 / 0$ & $0 / 0$ & $0 / 0$ \\
\hline 19 & $0 /-$ & $0 /-$ & $0 /-$ & $0 /-$ & $0 /-$ \\
\hline 20 & $0 / 0$ & $0 / 0$ & $0 / 0$ & $0 / 0$ & $0 / 0$ \\
\hline 21 & $0 / 0$ & $0 / 0$ & $0 / 0$ & $0 / 0$ & $0 / 0$ \\
\hline 22 & $0 / 0$ & $0 / 0$ & $0 / 0$ & $0 / 0$ & $0 / 0$ \\
\hline 23 & $0 / 0$ & $0 / 0$ & $0 / 0$ & $0 / 0$ & $0 / 0$ \\
\hline
\end{tabular}

aConstituents not shown have no applicable Colorado State water quality standard.

bDissolved nitrate was calculated by subtracting dissolved nitrite from dissolved nitrite-plus-nitrate.

,- no data.

oxygen, acute ammonia, or dissolved nitrate standards were observed in the drought samples, and of these constituents, only a small number of dissolved oxygen concentrations in the seasonal historical data were outside of the standard.

Colorado has established state water quality standards for 9 of the 48 pesticides analyzed (Colorado Department of Public Health and Environment, 2001). In the seasonal historical data, several exceedances of either the acute aquatic life or the fish ingestion standards occurred at two sites -2 and $21-$ for chlorpyrifos, p,p-DDE, and dieldrin (Table 6). In comparison, concentrations of the nine regulated pesticides did not exceed any criteria during the drought synoptic. It should be noted that current standards do not completely address potential risks to humans and aquatic life because there are no standards for many individual pesticides, pesticide mixtures, or degradation products and because certain potential effects, such as endocrine disruption, have not been fully assessed (Fuhrer et al., 1999).

\section{SUMMARY AND CONCLUSIONS}

Twenty-three stream sites in the South Platte River Basin of Colorado representing a range of forested, agricultural, and urban land uses were sampled from July through September 2002 to characterize water quality during drought conditions. Changes in biological activity, water temperature, and ground water contributions led to water quality changes during the drought; the pattern and magnitude of the response varied among sites and among constituents. The drought response of water temperature, dissolved oxygen concentrations, and dissolved nitrite-plusnitrate concentrations were significantly different among the forested, urban, and agricultural sites due to differences in nutrient sources, stream size, and water management. At some urban and agricultural sites, fertilizer application and point source discharges to streams with historical low flows likely contributed to increased nitrite-plus-nitrate concentrations and therefore increased primary productivity and increased dissolved oxygen concentrations that 
TABLE 6. Summary of the Percentage of Pesticide Concentrations Outside Colorado State Water Quality Standards in the Drought Data Compared to the Seasonal Historical Data (drought/seasonal historical). ${ }^{\mathrm{a}}$

\begin{tabular}{ccccccccc}
\hline $\begin{array}{c}\text { Site } \\
\text { Number }\end{array}$ & Alachlor & Atrazine & Carbofuran & Chlorpyifos & p,p-DDE & Dieldrin & Malathion & Parathion \\
Simazine
\end{tabular}

aConstituents not shown have no applicable Colorado State water quality standard.

bExceedances of acute aquatic life standard.

cExceedances of fish ingestion standard.

- , no data.

were not observed at the forested sites. Increased water temperatures at many forested sites during the drought decreased oxygen solubility and led to decreased dissolved oxygen concentrations. The increased water temperatures at these forested sites were not observed in other parts of the basin, which may be due to more efficient heating of the smaller streams in the headwater areas and the addition of cooler water from reservoirs, point sources, or ground water to the streams in some localized urban and agricultural areas. With a few exceptions, dissolved ammonia, Kjeldahl nitrogen, total phosphorus, and dissolved orthophosphate concentrations were similar to seasonal historical levels in all land use areas during the drought. Depending on the site, the number of pesticides detected and the total pesticide concentrations were higher or lower than the seasonal historical median.

The ability to extrapolate the results from sites monitored during this study to remaining portions of the South Platte River Basin is limited. Almost half of the study sites were in the Big Thompson River Basin, which comprises less than 5 percent of the total area of the South Platte River Basin. Much of the water in the Big Thompson River is diverted from the Colorado River Basin via the Adams Tunnel. In addition, all 11 sites in the Big Thompson River Basin were classified here as forested, and only three other sites in the South Platte River Basin were so classified. As a result, any conclusions reached about water quality at sites draining forested areas in the South Platte River Basin would be essentially synonymous with conclusions that have been drawn about sites in the Big Thompson River Basin. The appropriateness of generalizing the results from the sites in the Big Thompson River Basin, and similarly, generalizing the results from the few urban and agricultural sites included in the study, cannot be known without further study in other parts of the South Platte River Basin.

The results from this study indicate that drought conditions did affect water quality in parts of the South Platte River Basin. All sites monitored during the drought had at least one constituent that was elevated or depressed relative to seasonal historical data; however, the number of elevated or depressed values in the drought data at many sites was not as high as might be expected from such low streamflows. In addition, the pattern of the response during the drought differed across sites in different land uses; forested sites were somewhat more sensitive to drought conditions than urban and agricultural sites. Only four samples had measured concentrations that were outside Colorado state water quality standards. Although the small number of samples collected during the drought synoptic limited the degree to which stream impairment could be assessed, the low number of samples with concentrations outside established water quality standards suggests that the present regulatory framework may be robust even in extreme low flow conditions.

\section{ACKNOWLEDGMENTS}

This work was funded in part by the Northern Colorado Water Conservancy District, Jefferson County, the Big Thompson Watershed Forum, and the City of Fort Collins. Additional support for data analysis was provided by the Natural Resource Ecology Laboratory at Colorado State University. 


\section{LITERATURE CITED}

Caruso, B.S., 2002. Temporal and Spatial Patterns of Extreme Low Flows and Effects on Stream Ecosystems in Otago, New Zealand. Journal of Hydrology 257:115-133.

Colorado Department of Public Health and Environment, 2001. The Basic Standards and Methodologies for Surface Water (5 CCR 1002-31). Water Quality Control Commission,Regulation No. 31, $169 \mathrm{pp}$.

Colorado Department of Public Health and Environment, 2002. Classifications and Numeric Standards South Platte River Basin, Laramie River Basin, Republican River Basin, Smoky Hill River Basin. Water Quality Control Commission, Regulation No. 38, 65 pp.

Colorado General Assembly, 1923. South Platte River Compact 1923: 37-65-101 C.R.S. Available at http://www.cwcb.state.co.us/ Fact_Sheets/splattercompact1923.htm. Accessed in April 2004.

Colorado State University, 2004. Colorado Modified Palmer Index 2002. Colorado Climate Center. Available at http://ccc.atmos. colostate.edu/pdfs/Palmer2002.pdf. Accessed in April 2004.

Dennehy, K.F., D.W. Litke, P.B. McMahon, J.S. Heiny, and C.M. Tate, 1995. Water-Quality Assessment of the South Platte River Basin, Colorado, Nebraska, and Wyoming - Analysis of Available Nutrient, Suspended-Sediment, and Pesticide Data, Water Years 1980-92. U.S. Geological Survey Water-Resources Investigations Report 94-4095, 145 pp.

Denver Water, 2004. Snow Pack (Three Year Comparison) - Reservoir Levels and More. Available at http://www.water.denver.co. gov/reslevelsmore/pdfs/snow_pack.pdf. Accessed in April 2004.

Dodds, W.K., M.A. Evans-White, N.M. Gerlanc, L. Gray, D.A. Gudder, M.J. Kemp, A.L. Lopez, D. Stagliano, E.A. Strauss, J.L. Tank, M.R. While, and W.M. Wollheim, 2000. Quantification of the Nitrogen Cycle in a Prairie Stream. Ecosystems 3(6):574589.

Fishman, M.J., 1993. Methods of Analysis by the U.S. Geological Survey National Water-Quality Laboratory - Determination of Inorganic and Organic Constituents in Water and Fluvial Sediments. U.S. Geological Survey Open-File Report 93-125, 217 pp.

Fuhrer, G.J., R.J. Gilliom, P.A. Hamilton, J.L. Morace, L.H. Nowell, J.F. Rinella, I.D. Stoner, and D.A. Wentz, 1999. The Quality of Our Nation's Waters - Nutrients and Pesticides. U.S. Geological Survey Circular 1225, 82 pp.

Golladay, S.W. and J. Battle, 2002. Effects of Flooding and Drought on Water Quality in Gulf Coastal Plain Streams in Georgia. Journal of Environmental Quality 31(4):1266-1272.

Insightful Corp., 2000. S-Plus 2000 Professional Release 3. Reinach, Switzerland.

Kobayashi, D., K. Suzuki, and M. Nomura, 1990. Diurnal Fluctuation in Stream Flow and in Specific Electrical Conductance During Drought Periods. Journal of Hydrology 115:105-114.

Muchmore, C.B. and B. Dziegielewski, 1983. Impact of Drought on Quality of Potential Water Supply Sources in the Sangamon River Basin. Water Resources Bulletin 19(1):37-46.

NOAA (National Oceanic and Atmospheric Administration), 2002. Climate of 2002 - Colorado Drought. National Climatic Data Center. Available at http://lwf.ncdc.noaa.gov/oa/climate/ research/2002/jun/st005dv00pcp200206.html. Accessed in April 2004.

Schindler, D.W., 1997. Widespread Effects of Climate Warming on Freshwater Ecosystems in North America. Hydrologic Processes 11:225-251.

Tweto, Ogden, 1979. The Geologic Map of Colorado: Special Publication - The Geologic Map of Colorado. U.S. Geological Survey, Reston, Virginia.

U.S. Census Bureau, 2000. Census 2000 Redistricting Data Summary File. U.S. Census Bureau Technical Documentation Public Law 94-171, $223 \mathrm{pp}$.
USGS (U.S. Geological Survey), 1999. National Elevation Dataset Edition 1. U.S. Geological Survey Raster Digital Data, EROS Data Center, Sioux Falls, S.D. Available at http://gisdata.usgs. net/ned/. Accessed in April 2004.

USGS (U.S. Geological Survey), 2004. National Field Manual for the Collection of Water-Quality Data. U.S. Geological Survey Techniques of Water-Resources Investigations, Book 9, Chaps. A1-A9, 2 v., variously paged, 1997 to present. Available at http://pubs.water.usgs.gov/twri9A. Accessed in April 2004.

Vogelmann, J.E., S.M. Howard, L. Yang, C.R. Larson, B.K. Wylie, and N. Van Driel, 2001. Completion of the 1990s National Land Cover Data Set for the Conterminous United States from Landsat Thematic Mapper Data and Ancillary Data Sources. Photogrammetric Engineering and Remote Sensing 67:650-652.

Wetzel, R.G., 1983. Limnology. W.B. Saunders, Philadelphia, Pennsylvania.

Woodhouse, C.A., J.J. Lukas, and P.M. Brown, 2002. Drought in the Western Great Plains, 1845-56. Bulletin of the American Meteorological Society 83(10):1485-1493.

Zaugg, S.D., M.W. Sandstrom, S.G. Smith, and K.M. Fehlberg, 1995. Methods of Analysis by the U.S. Geological Survey National Water-Quality Laboratory - Determination of Pesticides in Water by C-18 Solid-Phase Extraction and Capillary-Column Gas Chromatography/Mass Spectrometry With Selected-Ion Monitoring. U.S. Geological Survey Open-File Report 95-181, 49 pp. 